\title{
Clinical and tomography evolution of frontal osteomyelitis: Case report
}

\section{Evolução clínica e tomográfica da osteomielite frontal: Relato de caso}

\author{
Raquel Crisóstomo Lima Verde', Luana Alves de Souza', Bruno Farias Lessa', Clara Mônica Figueiredo de Lima², \\ Marcus Miranda Lessa ${ }^{3}$, Hélio Andrade Lessa4.
}

\author{
1) Otorhinolarynghology Resident Physician of Professor Egdar Santos University Hospital - UFBA. \\ 2) Otorhinolaryngologist Doctor. Rhinology Fellow of Otorhinolarygology Department of Professor Egdar Santos University Hospital - UFBA. \\ 3) Otorhinolaryngology PhD of FMUSP. Adjunct Professor of Otorhinolarynghology Department of Professor Edgard Santos University Hospital - UFBA \\ 4) Otorhinolarynghology PhD by UFBA. Otorhinolarynghology Department Chief of Professor Edgard Santos University Hospital. \\ Institution: Otorhinolarynghology Department of Professor Edgard Santos University Hospital. \\ Salvador/BA - Brazil. \\ Mailing address: Raquel Crisóstomo Lima Verde - Dr. Clemente Ferreira st 139, Apto 101/201 - District: Canela - Salvador / BA - Brazil - Zip-code: 40110-200 - Telephone: \\ (+55 71) 8774-2704/(+55 71) 3283-8376 - E-mail: raquelclv@gmail.com \\ Article received in 2010 February $02^{\text {nd }}$. Article approved in 2010 July $18^{\text {th }}$
}

\section{SUMMARY}

Introduction: The frontal osteomyelitis is a complication of rhinosinusitis which can evolve to acute or chronicle. There is inflammatory reaction by the increasing of intraosseous pressure, ischemia and local necrosis, leading to bone abscess formation. There is no drainage, it will occur detachment of the periosteum, soft tissue invasion and worsening of ischemia with subsequent bone sequestration.

Method: Case report of an inpatient in an emergency service of another institution by the complication of rhinosinusitis who was referred to the Otorhinolaryngology Service of University Hospital Professor Edgard Santos of Federal University of Bahia.

Case Report: Male patient, 16 years-old, presented himself to the ER of another institution with cephalea, vomits and fever which evolved to periorbital edema and frontal to the left, moving to palpebral fluctuation and frontal. Subjected to frontal and palpebral abscess drainage, with broad-spectrum antibiotic therapy with no improvement. He was referred to our service keeping edema and fluctuation in region frontal and light edema in left periorbital region. The nasal endoscopy showed edema in meatus to the left and the computerized tomography showed fronto-ethmoid sinusitis to the left and signs of frontal osteomyelitis with bone sequestration and epidural empyema. Subjected to sinasal endoscopy surgery, external Access or removal of the frontal one affected and epidural empyema drainage. Evolved to the remission of the disease.

Final Considerations: Failure in the diagnosis and rhinosinusitis complication treatment can lead to sequalae and fatal complications. The diagnosis of the frontal osteomyelitis is confirmed by the clinical suspicion and confirmed by radiological examination. The surgery is indicated when the evolution is insidious, there is bone sequestration and intracranial complications.

Keywords: osteomyelitis, frontal sinusitis, tomography, evolution.

\section{RESUMO}

Introdução: A osteomielite frontal é uma complicação de rinossinusite que pode ter evolução aguda ou crônica. Há reação inflamatória com aumento da pressão intra-óssea, isquemia e necrose local, levando à formação de abscesso ósseo. Não havendo drenagem, ocorrerá descolamento do periósteo, invasão de partes moles e piora da isquemia com posterior sequestro ósseo.

Método: Relato de caso de um paciente internado em serviço de emergência de outra instituição por complicação de rinossinusite que foi encaminhado para o Serviço de Otorrinolaringologia do Hospital Universitário Professor Edgard Santos da Universidade Federal da Bahia.

Relato de Caso: Paciente masculino, 16 anos, apresentou-se ao serviço de emergência de outra instituição com cefaleia, vômitos e febre que evoluiu com edema periorbitário e frontal à esquerda, cursando com flutuação palpebral e frontal.Submetido à drenagem de abscesso palpebral e frontal, com antibioticoterapia de amplo espectro sem melhora. Encaminhado para o nosso serviço mantendo edema e flutuação em região frontal e edema leve em região periorbitária esquerda. A endoscopia nasal evidenciou edema em meato médio à esquerda e a tomografia computadorizada mostrou sinusite fronto-etmoidal à esquerda e sinais de osteomielite frontal com sequestro ósseo e empiema epidural.Submetido à cirurgia endoscópica nasossinusal, acesso externo para exérese do osso frontal acometido e drenagem do empiema epidural. Evoluiu com remissão da doença.

Considerações Finais: A falência no diagnóstico e no tratamento das complicações da rinossinusite pode levar a sequelas e complicações fatais.O diagnóstico de osteomielite frontal é firmado pela suspeita clinica e confirmado por exames radiológicos.A cirurgia está indicada quando a evolução for insidiosa, havendo sequestro ósseo ou complicações intracranianas.

Palavras-chave: osteomielite, sinusite frontal, tomografia, evolução. 


\section{INTRODUCTION}

Osteomyelitis can be defined as an inflammatory process accompanied by osseous destruction caused by an $\mathrm{n}$ infectious microorganism $(1,2)$. This clinical entity can affect varied bones in whole body, with the mandible, frontal bone, cervical spine, maxilla, nasal bone, temporal bone and the bones of the skull base reported in the literature as involved in osteomyelitis in head and neck (2).

Hear and neck osteomyelitis require great care as it can present complications, leading to important morbity and mortality, like meningitis, epidural empyema, subdural empyema, brain abscess and cavernous sinus thrombosis $(2,3)$. These complications can be presented in the course of a character of a silent disease, with the relatively asymptomatic patient attending, despite of epidural abscess and frontal lobe (4). Beyond the complications risks, it also presents greater anatomic difficulties and demanding a greater esthetics consideration $(2,3)$.

PRASAD et al.(2) showed frontal osteomyelitis as the second place in frequency in head and neck, only losing to mandible osteomyelitis. Chronical rhinosinusitis was pointed as the mains cause of frontal involvement

This pathology diagnosis must be based on typical clinical finding, including localized pain, frontal edema, abscess floating, deformity, instability, fertilization and rhino rhea, being associated to complaints of headache, photophobia, fever, irritability, vomiting and lethargy $(2,5,6,7)$. This diagnosis should be supplemented by radiological examination, such as high resolution of computerized tomography (CT) and scintigraphy with gallium-67 and technetium-99m. The osteomyelitis incidence is not established on the literature, and when complication such as frontal rhinosinusitis is presented, it can represent a diagnostic challenge, with possible delay in its recognition and evolving to a greater morbity.

The authors present the clinical and radiological evolution in case of frontal osteomyelitis, secondary to an acute rhinosinusitis.

\section{CASE RePort}

Male patient, 16 years-old, presented himself to the ER of another institution with cephalea, vomits and fever which evolved to periorbital edema and frontal to the left, moving to palpebral fluctuation and frontal. Subjected to frontal and palpebral abscess drainage under local anesthesia and remained hospitalized for 1 month and 15 days using parenteral broad-spectrum antibiotic, without improvement of the bulging front. After 45 days of the disease evolution, made several computerized tomography scans, the patient war referred to our Othorynolaringolgy Service of HUPESUFBA maintaining edema and floating in the frontal region and mild edema in the left periorbital region, without changes in the ocular mobility or visual acuity. The nasal endoscopy showed edema in the region of the left middle meatus and the computerized tomography of paranasal sinuses showed fronto-ethmoidal sinusitis in the left and signs of frontal osteomyelitis with bone sequestration and epidural empyema (Figures 1 to 4). Then, he was, subjected to endoscopic sinus surgery with approach to the frontal recess and frontal sinus drainage by otorhinolaringoloy team associated to external access to the team neurosurgeon for removal of affected frontal bone and drainage of epidural empyema. At the postoperative the patient evolved well and at the moment presents with complete remission of the disease (Figures 5 and 6 ).

\section{DISCUSSION}

At the age of antibiotic, the osteomyelitis is a rare complication of a frontal rhinosinusitis or direct trauma to the frontal bone $(3,8,9,10)$. The major related cases occurred after open fractures, however the bone infection can be occur by infection dissemination though soft tissues or minor injury, including acupuncture $(9,11)$. The rarity of this entity can be caused by the diagnosis delay.

The groups most affected are children and teenagers, like the patient in question, as the frontal sinus becomes pneumatized at six years-old and reaches to its adult configuration round 15 years-old. $(7,12)$.

The clinical course may be acute or chronic. In the acute, headache, purulent rhinorrhea, fever and edema of the eyelids are present (13). A soft depressible edema and painless at frontal bone (Pott Tumor) is pathognomonic for osteomyelitis of the frontal bone (13). The chronic is characterized by low fever, general malaise, pain, edema may also occur sino-cutaneous fistulas, sequestration and secretion through the bone with cyclic exacerbation (13). It can still occur neurological symptoms due to meningitis, extradural abscess, subdural or intraparenchymal (13).

The infection can be limited in a portion of the bone or involve many regions like bone marrow, cortex, periosteum and surrounding soft tissues (1). Due to the arrangement of mucous drainage, the infection of frontal sinus can spread itself to the coating bone in two, by direct extension or by spreading from a septic thrombus affecting multiple skull bones $(2,5,6)$. The sinusitis takes the osteomyelitis from external wall of frontal bone, it may progress to bone erosion and subperiosteal abscess. It yet may affect the internal wall 


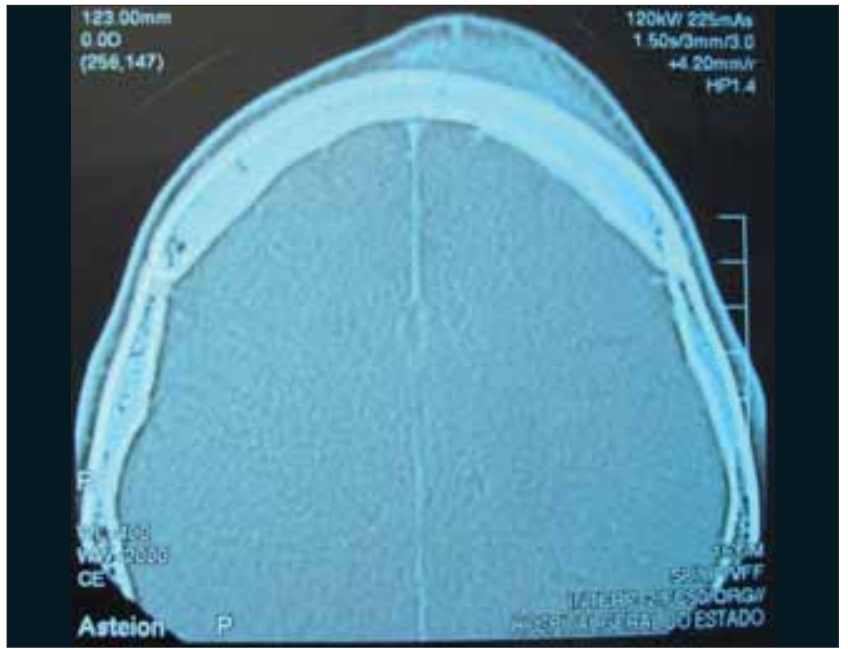

Image 1 .

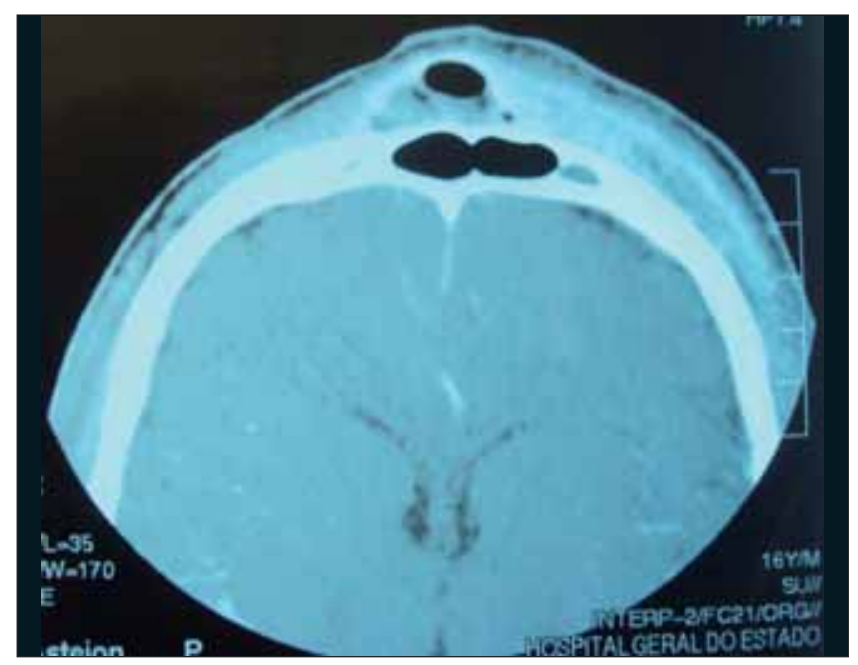

Image 3.

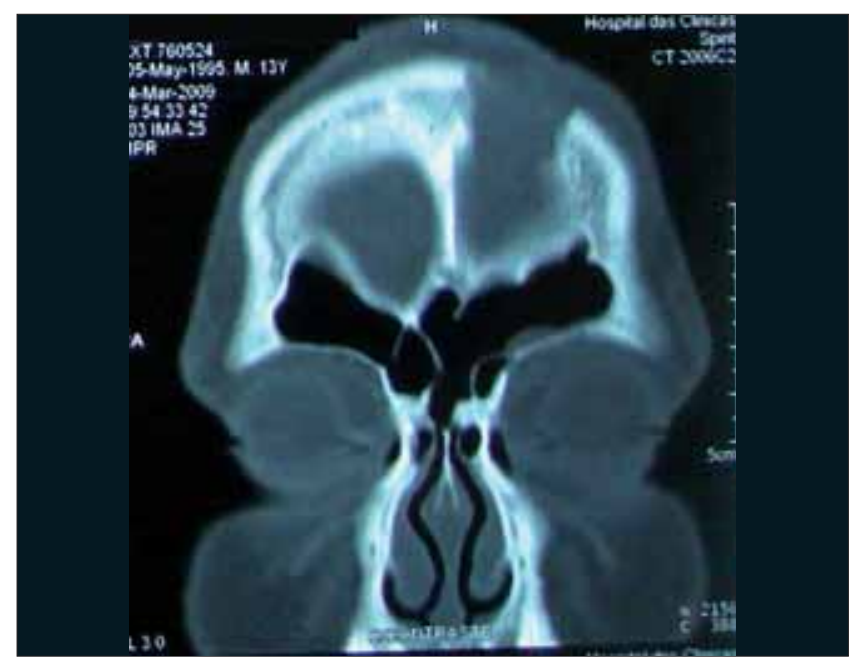

Image 5.

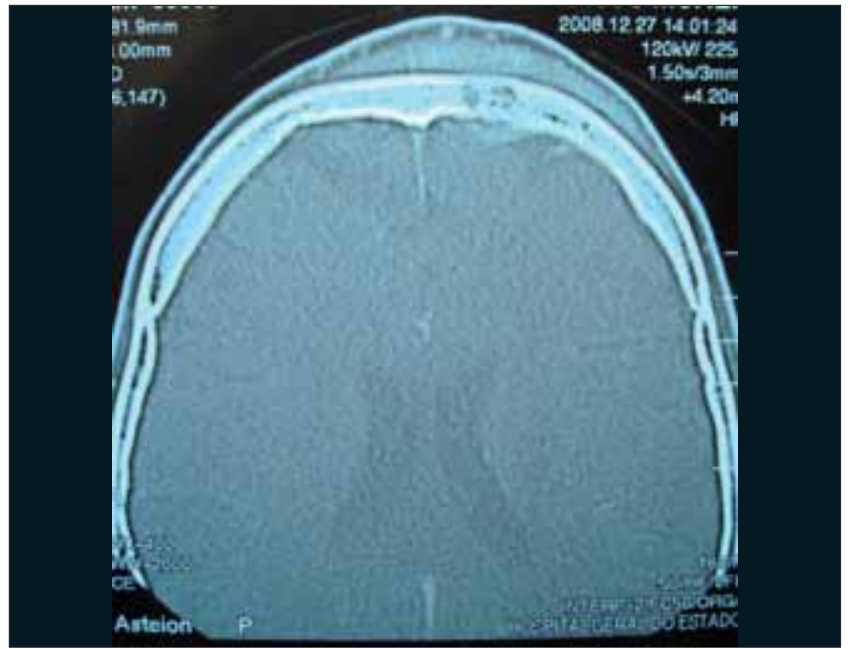

Image 2.

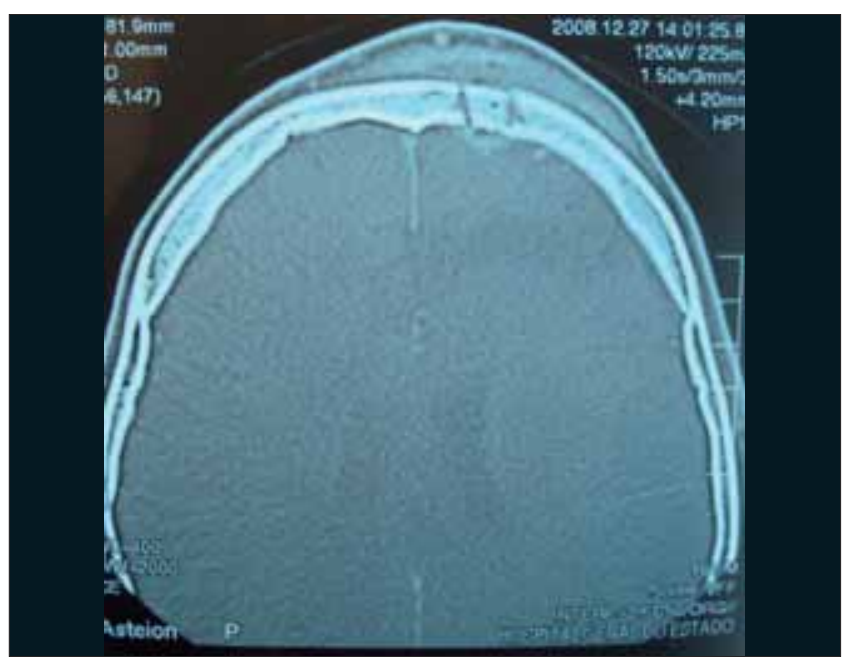

Image 4.

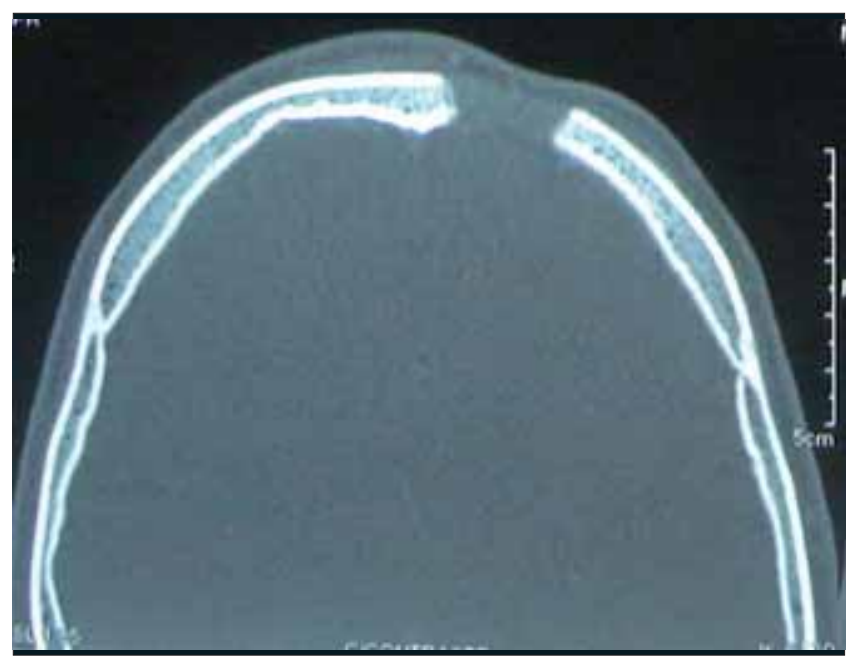

Image 6. 
resulting in epidural empyema, like the case of our patient, subdural collections and encephalitis. Hematogenous dissemination can occur by avalvulars diploic veins leading to the sagittal sinus thrombophlebitis, brain abscess and subdural empyema (7).

The microscopical examination of the osteomyelitis area reveals an acute suppurative inflammation where bacteria or other microorganisms are present. Many inflammatory factors and leukocytes contribute to the tissue necrosis and destruction of the trabecular bone matrix. Vascular channels are compressed and destroyed by the inflammatory process, and resulting in ischemia which contributes to bone necrosis. Bones segments devoid of blood supply may begin to separate themselves in order to form bone sequestration, may still harbor bacteria despite the antibiotic therapy(1). The nature relatively avascular and ischemic of the region infected and the sequestration produce an area of flow oxygen tension as well as an area that the antibiotic can not penetrate. The low oxygen tension effectively reduces the bactericidal activity of polymorphonuclear and favors the conversion of an infection in a previously aerobic to an anaerobic. The rate of diffusion of the antibiotic in the dead bone is so small that is frequently impossible to the microorganism reaches it despite the external concentration. This indicates ineffectiveness concentrations of antibiotic at the site of infection despite of the levels in serum indicate therapeutic concentration (2). Complications occur as a result of the infection dissemination via venous drainage of the frontal sinus or direct extension through the bone (8).

The conditions that change the bone vascularization, such as radiation, malignancy, osteoporosis, osteopetrosis, and Paget's disease predisposes to osteomyelitis. As with systemic diseases, such as diabetes mellitus, anemia e mal nutrition can cause changes in the organism defenses, and profoundly influence the course of osteomyelitis (2).

Patients with frontal osteomyelitis generally have polymicrobial infection. The microorganisms in the chronic osteomyelitis are similar to the acute, but more resistant, although the culture should direct the antibiotic chosen (6). The microorganisms more frequent in the acute osteomyelitis are Sthaphylococcus aureus, Streptococcus spp., anaerobic organisms, and in exceptional cases fungus $(3,6,7,10,11)$. When presenting intracranial complications the anaerobic are the predominant pathogens (7). The fact that empirical intravenous antibiotic therapy be started without delay to the surgical time is probably what influences the absence of pathogens in most cultures performed (7).

The diagnosis of this pathology, when suspected by the typical clinical findings, it must be supplemented by radiological examination. The simple radiography does not show changes in less than 07 to 10 days, and on the more $50 \%$ change in bone mineralization is required (4). The means of choosing the bones change detection is the computerized tomography $(3,6,8)$, it is done to evaluate the bone erosion extension and presence of intracranial infection (4). It is also particularly useful to identify pockets of gas or intramedullary increased density, that were found early, as well as small areas of cortical destruction and bone sequestration $(15,16)$. Initially, shows only swelling of soft tissues (Figure 1). The following are observed osteolysis and osteosclerosis (Figure 2) which already suggests frontal osteomyelitis (3). The periostitis, which is determined by bone neoformation occurs after detachment of the periosteum from 10 to 15 days, and in this phase, it can already be observed subperiosteal abscess (Figure 3). This phase is the transition of acute osteomyelitis to the chronic. In the following, we indentify bigger or smaller bone fragment devitalized which will necrose and it will constitute the bone sequestration, and then it establishes the chronic phase (Figure 4) (14). Magnetic resonance imaging can be used to investigate complications. The gallium-67 scintigraphy with technetium-99m help to confirm the diagnosis, determine the disease extension and the response to antibiotic therapy $(3,6,17)$. The positive examination with technetium-99m allows us to affirm the early osteomyelitis diagnosis. In the other hand, the use of gallium- $67 \mathrm{~m}$ is indicated to follow up resolution and determination of the infectious process (13).

The laboratory investigation usually is not helpful, it can present a doubtful leukogram, with erythrocyte sedimentation rate and C-reactive protein may be normal or high $(1,8)$.

The appropriate moment and the type of the procedure which must be taken is the reason of this discussion in the literature, as the early aggressive surgical treatment can result in a deforming procedure not necessary, howevera delay in the diagnosis and treatment of intracranial involvement or progressive disease may be associated with unnecessary morbidity and mortality (4).

The treatment more accepted in the literature is a course of antibiotics for six to eight weeks, associated to surgical treatment, which involve debridement of necrotic tissue and bone, obtaining the culture, handling of dead space, and when necessary, bone stability $(2,3,5,6,7,9,10)$. You can vary the level of approach, from the performance of endoscopic sinus surgery in osteomyelitis limited to secretion drainage, external approaches in the process of more destructive disease presenting the involvement of the anterior wall of the frontal sinus, and craniotomy in cases with extensive involvement of the posterior wall, this surgery can be associated to sinonasal endocospic surgery and to the other procedures for the secretion drainage (2). 


\section{Final Considerations}

The frontal bone osteomyelitis is a rare disease in the antibiotic age, however it must be refreshed like diagnostic suspected in patients with compatible symptomatology, due to the risk of the rate of morbidity and mortality increase with the advent of the complications, as well as by the esthetic deformity arising out of the treatment. The clinical course can be acute or chronic. In acute, headache, purulent rhinorrhea, fever and swollen eyelids are present and the tumor of Pott, pathognomonic of osteomyelitis of the frontal sinus. The chronic is characterized by low fever, general malaise, pain, edema may also occur sino-cutaneous fistulas, sequestration and secretion through the bone with cyclic exacerbation. The imaging modality of choice for the detection of bone changes is computerized tomography. It shows, in the beginning, swelling of soft tissues. Then, osteosclerosis and osteolysis, periostitis with subperiosteal abscess and, at last, the bone sequestration, which, establishes the chronic phase of osteomyelitis. Treatment should consist of a long course of parenteral antibiotics, as well as drainage and debridement of the lesion.

\section{Biblography RefERENCES}

1. Lew DP, Waldvogel FA. Osteomyelitis. Lancet. 2004 Jul 24-30, 364(9431):369-79.

2. Prasad KC, Prasad SC, Mouli N, Agarwal S. Osteomyelitis in the head and neck. Acta Otolaryngol. 2007 Feb, 127(2):194-205

3. Tuon FF, Russo R, Nicodemo AC. Brain abscess secondary to frontal osteomyelitis. Rev Inst Med Trop Sao Paulo. 2006 Jul-Aug, 48(4):233-5.

4. Gardiner LJ. Complicated frontal sinusitis: evaluation and management. Otolaryngol Head Neck Surg. 1986 Oct, $95(3$ Pt 1):333-43.

5. Marshall AH, Jones NS. Osteomyelitis of the frontal bone secondary to frontal sinusitis. J Laryngol Otol. 2000 Dec, 114(12):944-6.

6. Goldberg AN, Oroszlan G, Anderson TD. Complications of frontal sinusitis and their management. Otolaryngol Clin North Am. 2001 Feb, 34(1):211-25.
7. Guillén A, Brell M, Cardona E, Claramunt E, Costa JM. Potts puffy tumour: still not an eradicated entity. Childs Nerv Syst. 2001 May, 17(6):359-62.

8. Masterson L, Leong P. Potts puffy tumour: a forgotten complication of frontal sinus disease. Oral Maxillofac Surg. 2009 Jun, 13(2):115-7.

9. Wu CT, Huang JL, Hsia SH, Lee HY, Lin JJ. Potts puffy tumor after acupuncture therapy. Eur J Pediatr. 2009 Sep, 168(9): 1147-9. Epub 2008 Dec 5.

10. Minutilli E, Pompucci A, Anile C, Corina L, Paludetti G, Magistrelli $\mathrm{P}$, Castagneto $\mathrm{M}$. Cutaneous fistula is a rare presentation of Potts puffy tumour. J Plast Reconstr Aesthet Surg. 2008 Oct, 61(10):1246-8. Epub 2008 Jun 30.

11. Martinez-Diaz GJ, Hsia R. Potts Puffy tumor after minor head trauma. Am J Emerg Med. 2008 Jul, 26(6):739.e1-3.

12. Nudellman, LM; Santos, JPF; Cardoso, PRC; Tumor de Pott, Rev. AMRIGS. 2009 abr-jun, 53(2):188-191.

13. Neves M, Butugan O, Voegels RL, Complicações das Rinossinusites em: Rinologia e Cirurgia Endoscópica dos Seios Paranasais.1 ed.Rio de Janeiro: Revinter, 2006, v.1, p243255 (Doc. 205).

14. Hebert S, Barros Filho TEP, Xavier R, Pardini Jr AG, Infecções osteoarticulares Em: Ortopedia e Traumatologia: Princípios e prática. 4⿳亠丷⿵冂丶 ed, São Paulo: Artmed, 2009, p822830.

15. Horger M, Eschmann SM, Pfannenberg C, Storek D, Dammann F, Vonthein R, Claussen CD, Bares R. The value of SPET/CT in chronic osteomyelitis. Eur J Nucl Med Mol Imaging. 2003, 30:1665-1673.

16. B. Sammak, M. Abd El Bagi, M. Al Shahed, D. Hamilton, J. Al Nabulsi, B. Youssef and M. Al Thagafi. Osteomyelitis: a review of currently used imaging techniques. Eur Radiol. 1999, 9:894-900.

17. Altman KW, Austin MB, Tom LW, Knox GW. Complications of frontal sinusitis in adolescents: case presentations and treatment options. Int J Pediatr Otorhinolaryngol. 1997 Jul 18, 41(1):9-20. 